\title{
Brevísima historia de la risa en la hagiografía del Viejo y del Nuevo mundo: tres tipos de la prosa franciscana
}

\section{A Very Short History of Laughter in the Hagiography of the Old and the New World: Three Types of the Franciscan Prose}

\section{Marcos Cortés Guadarrama}

Universidad Veracruzana

MÉXICO

marccortes@uv.mx

[Hipogrifo, (issn: 2328-1308), 6.1, 2018, pp. 77-102]

Recibido: 06-02-2017 / Aceptado: 30-03-2017

DOI: http://dx.doi.org/10.13035/H.2018.06.01.07

Resumen. En un breve recorrido histórico (del siglo XV al XVII), en el presente artículo propongo analizar el tratamiento que tres hagiógrafos le han dado a la risa. Me limito al estudio de modelos narrativos franciscanos: un texto de un anónimo Flos sanctorum medieval; una Crónica renacentista, escrita por fray Toribio de Benavente, «Motolinía»; y, finalmente, una Relación barroca, del criollo fray Luis Jerónimo de Oré. Se pretende demostrar que la risa hagiográfica tiene características únicas, propias de este género literario de gran popularidad en la antigüedad.

Palabras clave. Risa; hagiografía; Flos sanctorum; «Motolinía»; Luis Jerónimo de Oré.

Abstract. In a short historical overview (15th and 17th century), this article analyzes the approach to the theme of laughter of three hagiographers. I will confine myself to the study of Franciscan narrative models: a text of an anonymous, a medieval Flos sanctorum; a chronicle from the renaissance written by fray Toribio de Benavente, «Motolinía»; and finally, a baroque document of the creole fray 
Luis Jerónimo de Oré. The purpose is to show that hagiographic laughter has its own characteristics, specific to this literary gender, which was very popular in ancient times. de Oré

Keywords. Laughter, Hagiography; Flos sanctorum; «Motolinía»; Luis Jerónimo

\section{INTRODUCCIÓN}

La Relación de la vida y milagros de san Francisco Solano es un documento que contribuyó con el proceso de beatificación y, finalmente, con la canonización de uno de los cuatro santos del virreinato peruano'. El autor de este texto es el franciscano fray Luis Jerónimo de Oré, un experimentado escritor criollo cuyo legado se reparte en varias obras de notable importancia para la catequesis y la propaganda teológica, tales como el Symbolo Cathólico Indiano (1598), redactado en castellano, latín, quechua y aimara; el Rituale, seu manualum peruanum (1607); los Mártires de Florida (1617); Corona de la Sacratísima Virgen María (1619), etc., y, por supuesto, la obra que se estudia en el presente trabajo, la cual fue «comandada en Madrid en el año de $1613 »^{2}$ por el Comisario General de la orden Franciscana para las indias, fray Antonio de Trejo.

La Relación de la vida y milagros de san Francisco Solano es resultado de una tradición literaria que comenzó en la más temprana antigüedad cristiana, con los documentos que dieron cuenta del martirio de los fieles ${ }^{3}$. Así pues, por lo menos con quince siglos de evolución, contaminación con otros géneros literarios y enriquecimiento a cuestas, la Relación es -entre otras cosas - ejemplo rotundo de una vita ${ }^{4}$ del Barroco: muestra la forma en que los hagiógrafos del siglo XVII trataron a los héroes de Dios, exaltando valores morales no tan explotados en otras centurias, como, por ejemplo, «el hombre de acción más que al hombre contemplativo, al hombre virtuoso más que al hombre milagroso» 5 .

1. El del Sur fue el único de los virreinatos americanos en lograr esta hazaña. No obstante, santa Rosa de Lima, la primera santa en ser canonizada en 1671, fue celebrada como propia en la Nueva España con textos como la Estrella de Occidente, de Pedro Castillo, una biografía de la peruana donde encontramos el epíteto de «lustroso honor de la Nueva España» (Rubial, 2001, p. 67). El segundo, santo Toribio Alfonso de Mogrovejo fue canonizado en 1726 -en el mismo año en el que Francisco Solano, quien antes había sido beatificado en 1675- y el último, san Martín de Porres, beatificado en 1837 y canonizado en 1962.

2. Cook, 1998, p. XVI

3. «La primera forma de la literatura hagiográfica, y casi la única en estos siglos iniciales, está constituida, pues, por las Actas de los mártires. Delehaye (pp. 105-109) las clasificó según su historicidad, que va desde el rigor documental hasta la falsedad absoluta» (Baños, 2003, p. 18)

4. En las vitae se nos muestra un perfeccionamiento gradual del héroe; como la ascensión de una escalera, paso a paso irá subiendo peldaños, dando pruebas de su virtud. Esto a diferencias de las Actas de los mártires, donde la narración se limitaba al enfrentamiento de dos bandos: perseguidores / mártires, todo ello con son sus respectivas consecuencias: detención, interrogatorio y martirio (Baños, 2003, p. 20)

5. Rubial, 2001, p. 38 
Al presentarse como una «Relación» ${ }^{6}$ nos encontramos dentro de las fronteras narrativas de un documento de corte legal, destinado a encarar los avatares de un largo y estricto proceso burocrático ante las autoridades eclesiásticas y ante las reformas impuestas por el papa Urbano VIII. Desde su llegada como cabeza de la Iglesia católica en 1623, se encargó, por ejemplo, de prohibir la impresión de libros que contuvieran evidencias de santidad, milagros, visiones, etc., sin el permiso de la «Sagrada Congregación de Ritos» y, además, se aseguró de someter a los autores a jurar bajo protesta de «no dar autoridad alguna a hechos sobrenaturales y de sólo hacerse eco de opiniones humanas»?. Por lo tanto, con estos imperativos rótulos legislativos, se explica por qué el texto hagiográfico barroco debe, por fuerza, manifestar ecuanimidad, evidencia y análisis de los elementos que argumenta con el fin de presentar un óptimo ejemplo de auténtica virtud espiritual cristiana.

La obra de nuestro franciscano cumple con estos requisitos, e incluso así lo consigna al inicio, pues aclara que fue: «Sacada por el padre fray Luis Jerónimo de Oré de seis informaciones jurídicas, hechas por los ilustrísimos señores arzobispos y obispos de Sevilla, Granada, Lima, Córdoba, Málaga, y de otra información»8. Es decir, se pretende manifestar la procuración de un cambio formal en ésta y en la mayoría de las vitae barrocas -aún en deuda con el ars praedicandi y sus recursos retóricos medievales ${ }^{9}$-, en donde es indispensable el testimonio para evitar la fantasía y la invención popular al momento de referir a un personaje digno de ser canonizable. Así pues, a diferencia de la hagiografía de la Edad Media, época que podría ser considerada como una verdadera edad dorada de la santidad, donde a los hagiógrafos ${ }^{10}$ les bastaba emplear anécdotas fantasiosas y dejar correr la imaginación para potenciar las cualidades taumatúrgicas de sus protagonistas ${ }^{11}$, en la hagiografía barroca hay un «abuso de alardes de erudición y digresiones» ${ }^{12}$ para manifestar rasgos prodigiosos similares en sus biografiados.

6. La Relación acerca de las antigüedades de los indios, de fray Ramón Pané; las Cartas de relación, de Hernán Cortés; La Brevísima relación de la destrucción de las indias, de Bartolomé de las Casas; la Relación de la Nueva España, de Alonso de Zorita; la Verdadera relación de la conquista del Perú, de Francisco Jerez; etc., son testimonios que pueden dar una clara idea de la «Relación» como documento legal cuya ductilidad se ajusta a distintos propósitos, pero siempre teniendo en cuenta informar a las máximas autoridades laicas o religiosas del estado de las cosas en los territorios sometidos a la corona. 7. Rubial, 2001, pp. 37-38.

8. Oré, Relación de la vida y milagros de san Francisco Solano, 1998, p. 1. Todas las referencias a la obra de fray Luis Jerónimo de Oré se toman de la edición de Cook. En adelante anotaré el número de capítulo y la página.

9. Las primeras tres fases preparativas de discurso oratorio presentes en la literatura hagiográfica son: I. Inventio, II. Dispositio y III. Elocutio. Ver Baños, 2003, pp. 52-57; y Beristáin, 2001, pp. 273-277, 158160 y 165 .

10. Representados, como ejemplo, por Gregorio Magno, y sus Diálogos o su Vida de san Benito y otras historias de santos y demonios. Existe una moderna edición en español a cargo de Galán, 2010.

11. La consecuencia de este tipo de narración hagiográfica fue que los elementos maravillosos, por vía del milagro, se repitieron ad nauseam, creando vidas fabulosísimas y de suma popularidad en la Península Ibérica durante la Edad Media, como fue el caso de san Antolín. Ver Cortés Guadarrama, 2016c. 12. Rubial, 2001, p. 41. 
No obstante, la hagiografía barroca todavía guardó, en la mayoría de los casos, algo de la frescura de los Flores sanctorum medievales ${ }^{13}$. Efectivamente, incluso cuando la Relación de la vida y milagros de Francisco Solano se concibió como un documento administrativo para altos eclesiásticos encargados de legislar la promoción de un venerable -y no como una obra de entretenimiento ascético, para ser leída, por ejemplo, en el refectorio conventual, como lo prueba cierta epístola proemial de un Flos sanctorum renacentista ${ }^{14}$-, es un texto de gran interés para la conceptualización de una poética literaria del escrito hagiográfico barroco y su evolución desde las fuentes textuales franciscanas medievales. De hecho, aun cuando el hagiógrafo criollo persiguió «mostrar las cosas como son», mediante la precisión, la objetividad y el análisis de la vida de Francisco Solano, terminó por imponer a su prosa legal la imaginería de una obra literaria; la cargó con la misma poética que da lugar a la trama, a la metáfora y la figuración ${ }^{15}$, e incluso, a partir del manejo estético de estos recursos retóricos, dio lugar a la risa, no como expresión de la tontería y la maldad, la cual vive encarnada en graciosos marginales y villanos sarcásticos en la comedia nueva y las innovaciones lopescas - género por excelencia del barroco hispánico-, sino como expresión de la alegría (laetitia) temperada, ejemplar; una risa que no responde necesariamente a lo cómico, sino a lo meramente hagiográfico, a lo que insta la santidad, tal y como se verá más adelante.

Así pues, el propósito del presente artículo es estudiar cómo se ha manifestado esta risa hagiográfica en la prosa de tres distintos autores a lo largo de tres siglos. Esto con la finalidad de intentar demostrar que, incluso en los textos más ascéticos y burocráticos - como el caso de la obra de Luis Jerónimo de Oré-, hay espacio para este fenómeno humano tan ligado a la imperfección, a lo bajo, a lo feo, etc., en la literatura religiosa.

Como este no es el lugar para un dilatado análisis de las fuentes textuales, me he limitado a los siguientes ejemplos de interés para el estudio del franciscanismo:

1) Una vida de san Francisco de Asís recogida en el Flos sanctorum con sus ethimologías, compendio enciclopédico y magna obra del siglo XV, ejemplo de la respuesta que dio la Península Ibérica a la acogida y transmisión de la Legenda aurea dentro de sus fronteras. El mencionado Flos sanctorum comprende casi todo el año de festividades del calendario litúrgico cristiano; se caracteriza por incluir -junto a las etimologías de los nombres de los santos - varios milagros eliminados en otros santorales posteriores debido a su marca netamente maravillosa y novelesca.

2) La Historia de los indios de la Nueva España del franciscano fray Toribio de Benavente, «Motolinía», obra miscelánea y una de las primeras y más interesantes crónicas de la evangelización americana, en la que la risa figura en varios momen-

13. La mayoría de los especialistas están de acuerdo con esta postura. Aragüés, por ejemplo, no deja de señalar que, la familia de legendarios a la que pertenece el Flos sanctorum que aquí se estudiará, siempre dio cabida a lo novelesco y a la hagiografía de corte más popular. Por su parte, así también lo ve Rubial (2001, p. 41) cuando estudia los modelos de santidad barrocos en la Nueva España: el ermitaño, el mártir, la religiosa y el misionero.

14. Aragüés, 2014, p. 34.

15. Sobre la teoría de los tropos de White, ver Tozzi, 2003, pp. 11-23. 
tos de la misma, tanto por la declarada intención providencialista del autor, como por las acciones de sus protagonistas: los indios.

3) La Relación de la vida y milagros de san Francisco Solano, de fray Luis Jerónimo de Oré, obra que reviste con ropajes barrocos una larga tradición de tópicos literarios que se remontan, si no a la vida del mártir san Policarpo (del siglo II), sí a Atanasio de Alejandría y su Vida de Antonio del siglo IV d. C., vita donde, por primera vez, se sustituía «al héroe pagano por un equivalente cristiano que era totalmente humano $y$, sin embargo, tan poderoso como cualquier hombre divino» ${ }^{16}$.

\section{EL HAGIÓGRAFO ANÓNIMO Y LA RISA MEDIEVAL}

En la cosmogonía cristiana, Dios y Espíritu Santo se revelan por la fe, pero, en última instancia, es un «Dios escondido» ${ }^{17}$ que se encarna en el Hijo, Jesús, quien fue humillado por los hombres. Es decir, a diferencia de otras religiones primitivas, donde el mundo se crea por la risa y la franca carcajada de los dioses ${ }^{18}$, en el cristianismo no hay tal libertad, antes se exalta lo contrario: el sufrimiento. Por lo tanto, la risa presente en esta teología -representada por el texto bíblico y otros derivados textuales posteriores - no debe pasar desapercibida. La risa en el cristianismo, aun escaza, meras gotas en un océano de doctrina religiosa y ejemplaridad en el género literario que aquí se estudia, debe verse como un axis mundi que pone en contacto dos espacios, el de lo sagrado y el de lo profano ${ }^{19}$.

Efectivamente, la risa y el cristianismo no parecen ir de la mano, la primera está relacionada con la imperfección y el segundo intenta contener los impulsos de la naturaleza humana, en la cual, junto a todas las excreciones del cuerpo, la risa parece que «se emplaza en el mundo de lo bajo» ${ }^{20}$. Es por ello, quizá, que la risa se asocia como una consecuencia tras el pecado original, y se considera, por lo tanto, como decadencia ${ }^{21}$. En la literatura bíblica, por ejemplo, no se menciona nunca que Cristo haya reído de manera «buena»; los evangelistas, por otra parte, van en contra de la risa como manifestación de la burla y de la mofa blasfemas. Y, en resumen, como en ningún momento del libro sagrado se dice que «Jesús haya reído

\footnotetext{
16. Palmer, 2014, p. 10.

17. Xirau, 2004, p. 125.

18. Minois (2015, p. 25) nos recuerda un bello ejemplo sobre este tema al inicio de si indispensable libro: de la risa de un dios nacen otros dioses, la luz, el agua, la generación, el destino y el tiempo.

19. Asumo la distinción conceptual de estos términos conforme a las ideas planteadas por Mircea Eliade en Lo sagrado y lo profano.

20. Beltrán, 2016, p. 15

21. En la Biblia la risa aparece por primera vez después del libro del Génesis. Debemos recordar que el cristianismo medieval convirtió en pecado sexual lo que originalmente era un pecado de soberbia intelectual (Le Goff, 2008, p. 52). Es decir, la risa nace con la aberración del cuerpo que culmina es sus aspectos sexuales, o sea, la mácula y la imperfección del hombre; sólo a través de éstos es que la risa se opone a las tres virtudes teologales, la fe, la esperanza y, principalmente, la caridad, virtud de gran importancia para el credo cristiano, como puede leerse en san Pablo: «si [...] no tengo caridad soy como bronce que suena o címbalo que retiñe [...] si no tengo caridad, no soy nada [...] no teniendo caridad, nada me aprovecha» (citado por Xirau, 2004, p. 125).
} 
alguna vez, entonces no lo hizo, y como los cristianos han de imitarlo en todo, no deberían reír $\rangle^{22}$.

Esta tradición fue seguida por los padres de la Iglesia y fue heredada a los hagiógrafos como Santiago de Vorágine y, con ello, fue también el mismo legado que recibió el anónimo autor ${ }^{23}$ del Flos sanctorum con sus ethimologías, derivación en lengua castellana con sus propias y singulares aportaciones que se alejan, hasta cierto punto, de su fuente: la Legenda aurea ${ }^{24}$. Así pues, no encontraremos textos propiamente humorísticos en este santoral, lo cual no quiere decir que sea un texto donde no haya lugar para la risa. De hecho, podría pensarse, con base en la asociación de la risa con el mundo de lo corpóreo, de lo bajo, que la risa solo pertenecería a los diablos ${ }^{25}$ y su risa demoniaca (scurrilitas, cachinnitas ${ }^{26}$ ), ligada al exceso gestual y a la burla. Esta clase de risa se caracteriza por presentar dos rasgos esenciales: su intento por descomponer una buena trayectoria o un buen propósito cristiano y su falta de mesura. Leemos por ejemplo la siguiente anécdota presente en la vida de san Gregorio:

Cuenta sant Juan Diácono, que conpuso la vida de sant Gregorio, que él escriviendo la su vida, aparesciole uno vestido en manera de sacerdote estando [él] durmiendo así commo si escriviese al candil. E era ves[fol. 65a]tido de una vestidura blanca e delgada, en manera que parecía de yuso una saya muy negra. E allegándose a él, tenía los carrillos finchados como de reír. E preguntóle Juan por qué omne de tan gran oficio commo él, por qué se reía de grand locura, e dixo él:

-Porque tú escrives de los muertos que viste bivos.

E díxole Jhuan [sic]:

Maguer que non lo vi por la cara aquél de quien yo escrivo, empero conóscole por sus dichos.

E dixo el otro:

- Segund que me semeja, tú feziste lo que quisiste, e yo non quedaré de fazer lo que pudiere 27 .

22. Minois, 2015, p. 143.

23. Al parecer el autor de nuestro Flos sanctorum se esforzó por no dejar ninguna huella de él, limitando su labor a la de un mero copista, quien, no obstante, pareció preocupado por revisar nuevos materiales y releer la fuente latina para entregar a la imprenta un nuevo y más "científico" legendario castellano. (Aragüés, 2014, p. 32 y Flos sanctorum con sus ethimologías, ed. Cortés Guadarrama).

24. Para un panorama completo de esta obra, ver Flos sanctorum con sus ethimologías, ed. Cortés Guadarrama y Cortés Guadarrama, 2016b.

25. Una de las características de los diablos en la literatura hagiográfica es el hedor que dejan tras aparecerse. Sin embargo, en la vida anónima de Simeón el estilita, de gran popularidad tanto en el Oriente como en el Occidente cristiano, se menciona como atributo de santidad el mal olor de despedía Simeón. Ver Palmer, 2014, pp. 48-49.

26. Risa que en nada se parece a la eutrapelia, como se verá más abajo. Sigo las precisiones de Aragüés (2005, p. 250), sobre la pertinencia de la risa cristiana «una risa investida, ante todo a partir de la Summa de Santo Tomás, con un nombre de impronta aristotélica».

27. Flos sanctorum con sus ethimologías, ed. Cortés Guadarrama, p. 269 
Pero también el hagiógrafo medieval puede servirse de esta risa «de grand locura» para escarnecer al enemigo del bien. Su exageración, su scurrilitas y cachinnitas ${ }^{28}$, puede ser empleada en su contra para someterlo a una ridiculización, presentándolo en los sitios más inconmensurables dentro del recuento de una vida ejemplar y santa; por ejemplo, metido dentro de una lechuga. Leemos en la lectura doctrinal de la «Exaltación de la Cruz»:

Cuenta sant Gregorio, in libro Diagolorum [sic], que una monja entrando en un huerto vio una lechuga e codiciola. E olvidósele de fazer la señal de la cruz, e mordiola atrevidamente e luego fue demoniada. E veniendo a ella sant Equecio, el diablo començó a llamar, e dezir: «¿Qué fize yo?, estávame la lechuga, e vino ella e mordiome». Enpero mandole salir este sancto, e luego salió della29.

El hagiógrafo medieval tampoco desperdiciará la oportunidad de reírse del diablo a través de uno de sus protagonistas más delicados: la bella y docta doncella santa, quien, en la ficción, carece de la fuerza bruta natural en el varón, apta para la lucha cuerpo a cuerpo. Así pues, por citar un ejemplo más, mueve hacia lo risible el gran temor que infunde santa Juliana a uno de los siervos de Satán:

Entonce mandola degollar, e mientra que la levavan a degollar, apareció el diablo en semejança de mancebo, diziendo a grandes bozes:

- ¡Non la perdones en ninguna manera, ca denostó a nuestros dioses e a mí me açotó esta noche fieramente!

[fol. 54b] E abriendo Juliana los ojos un poco por al diablo ver, fuyó dando grandes bozes, diziendo:

-¡Ay mesquino! ¡Aún me quieres prender e ligar!30

Distinguimos hasta ahora dos tipos de risa que emplea el autor medieval: la risa demoniaca y, a partir de sus mismas características inherentes, una risa utilizada en su contra: la burla del demonio. Ambas son las primeras manifestaciones del fenómeno, aunque, definitivamente, no son exclusivas de la literatura hagiográfica, pues están presentes en la literatura folklórica y se trata en el fondo de un tipo de risa «más marcadamente axiológica, pues sus figuras expresan valores puros» ${ }^{31}$.

Ahora bien, si en las vitae lo que se pretende es enseñar una lección moral sobre los extremos de una realidad determinada, es decir, entre el bien y el mal, es

28. Sin embargo, a pesar de que la risa demoniaca (scurrilitas, cachinnitas) es la del gesto exagerado, existe un tipo de santidad que responde también a estos patrones tan relacionados con el diablo, me refiero a los «santos locos», ascetas que servían a Dios haciéndose pasar por enfermos de locura. En teoría, se descubría su auténtica santidad hasta su muerte, pero si alguien lo hacía antes de la misma, estos «locos por la causa de Cristo» realizaban una acción sumamente insensata para que se eliminará toda sospecha de virtud. Ejemplo de este tipo de hagiografía es La vida de Simeón el Loco, de Leoncio de Neápolis. Ver Palmer, 1999, pp. 14-17 y 22-24.

29. Flos sanctorum con sus ethimologías, ed. Cortés Guadarrama, p. 431.

30. Flos sanctorum con sus ethimologías, ed. Cortés Guadarrama, p. 246.

31. Beltrán, 2015, p. 32. Sobra decir que estos valores son: el diablo / el mal y, por la otra cara de la moneda: el santo / el bien. 
de esperarse que no solo el diablo pueda reír - sin mesura en su caso- o que la risa se limite a la burla de este personaje. También el santo -biografiado en este Flos sanctorum mediante el recurso retórico de la abbreviatio ${ }^{32}$ - puede y tiene este derecho. Su risa (eutrapelia), en la mayoría de los casos, no pertenece al mundo profano, es decir, la realidad del defecto; es una risa eutrapélica que proviene desde el ascetismo, de la moderación, un paréntesis puntual a un mundo de contención o la culminación premiada de un proceso de perfección. Por ejemplo, esa bella risa de san Lorenzo que muy pocos recuerdan de su leyenda, cuando, ya enterrado, se entera que en el mismo sepulcro yacerá san Esteban:

E sant Llorente dava a entender que le plazía, porque venía su hermano morar allí cabe sí, pareciendo que se reía, diole lugar en el su sepulcro, dexándole quanto la meitad del vazío ${ }^{33}$.

Más adelante volveremos a esta risa eutrapélica y su pertinencia casi exclusiva de la literatura hagiográfica. Ahora me interesa destacar otra clase de risa propia del santo: la risa combativa, un arma defensiva que se carga con la fe y que mueve a la alegría desmedida, casi un éxtasis, cuando, por ejemplo, se alcanza la consagración cristiana mediante un bautizo de sangre: el martirio. Famoso es el pasaje de san Lorenzo (al parecer uno de los santos más risueños del calendario litúrgico) cuando pide a sus verdugos que le den la vuelta para que esté bien asado por los dos lados ${ }^{34}$; sin embargo, un pasaje menos conocido de su vida es aquél que, recibiendo martirio con azotes de pértigas de hierro y plomo, gracias a su risa, convierte a un hombre al cristianismo, demostrando el poder taumatúrgico de esta risa de combate:

E mandole açotar otra vegada, commo de primero.

Sant Llorente, reyéndose, dio gracias a Dios e rogó por los que aí estavan. En esa ora creyó un cavallero, que dezían Romano, e dixo a sant Llorente:

- Beo estar ante ti un mancebo muy fermoso, e alinpiar los tus mienbros con una sávana de lino. Por ende, conjúrote por Dios que non me desanpares, mas aprisa me ven a baptizar ${ }^{35}$.

Nuestro anónimo hagiógrafo no eliminó pasajes de esta naturaleza. Sí borró, en cambio, ciertas anécdotas, como aquélla de la vida de san Antonio, cuando un arquero le recriminó su recreo junto a un grupo de monjes que lo acompañaban. El santo terminó por demostrarle con una alegoría que los consagrados al ascetismo necesitan, por momentos, hacer un alto en las prácticas de penitencia o corren el riesgo de estropearse por la tensión constante, como un arco:

32. Recordemos que la misión de un Flos sanctorum es la de compilar el mayor número de santos posibles, por lo tanto no hay lugar para la amplificatio, aunque otra rama de las dos conocidas de los Flores sanctorum ibéricos, a la que no pertenece el Flos sanctorum con sus ethimologías, sí que se decantará por este recurso: la Compilación A o Gran Flos Sanctorum, Ver Thompson, 1986-1987, pp. 17-28.

33. Flos sanctorum con sus ethimologías, ed. Cortés Guadarrama, p. 483.

34. Flos sanctorum con sus ethimologías, ed. Cortés Guadarrama, p. 507

35. Flos sanctorum con sus ethimologías, ed. Cortés Guadarrama, p. 506. 
Quidam sagittarius beatum Antonium cum fratribus gaudentem quadam vice conspexit et ei displicuit. Cui Antonius: «Pone sagittam in arcu et trahe». Quod et fecit. Cumque ho secundo et tertio fieri mandasset, dixit sagittarius: «Tantum thahere potero quod de eius fractione dolebo». Cui Antonius: «Sic est in opere dei, quoniam si supra mensuram tendere vellemus, citius frangeremur; expedit ergo rigore, aliquando relaxari». Hoc audiens ille edificatus recessit ${ }^{36}$.

Me permito señalar que este no es un pasaje cómico y que no toda risa supone un tipo de diversión y que tampoco se representa aquí un juego o diversión que implique risa ${ }^{37}$. Esta es precisamente la cuestión a proponer en este artículo: ejemplos de risa hagiográfica (eutrapelia), exclusiva de nuestro género literario: una risa moderada, atenuada, casi una sonrisa, que bien define Aragüés: «La risa se constituye en sí como emblema de esa victoria moral, pero lo hace, ante todo, a partir del reconocimiento de superioridad intelectual del santo, otorgando un sentido trascendente a la sabiduría, al ingenio, a la astucia incluso» ${ }^{38}$. La risa eutrapélica es, en este caso, aquella que ocurre en el breve tiempo profano del religioso, entregado por completo al tiempo sagrado de seriedad y austeridad propios de su credo. Juan de Salisbury aclara el concepto de esta risa eutrapélica a partir de «los beneficios de la modestia hilaritas», al igual que san Bernardo y su «risus moderatus et rarus sine cachinno (sin carcajadas), sintagma que aúna esa moderación en el tono de la risa con su propio carácter excepcional, esporádico, de la vida del cristiano»39.

Por otra parte, ante tal potencia providencial, el hagiógrafo corría el riesgo de hacer parecer a sus protagonistas como demasiado perfectos, que incluso dominan la risa moderada, sutil e ingeniosa y, con ello, incurriría en uno de los mayores pecados del virtuoso de Dios: la soberbia ${ }^{40}$. Para evitar esta situación, el autor medieval también nos ofrece pasajes donde se aclara que solo existen dos tipos de risa y que los santos incurren, exclusivamente, en una de ellas, tal y como se cuenta en la vida de san Bernardo: "Nunca en manera rió que non tomase buen continente» ${ }^{41}$. En este mismo tenor de la risa «buena», llega a regalarnos razonamientos cándidos, con la llaneza de un argumento infantil, que ponen solución a las grandes incógnitas del credo cristiano en relación con, por ejemplo, la circuncisión de Cristo:

\footnotetext{
36. Legenda aurea, 52-59.

37. A esta conclusión llega el médico francés Laurent Joubert (1529-1582) en su Tratado de la risa. No descartamos las aportaciones de la historia de otras ciencias, como la médica, para un tema de estudio como el que aquí se propone. Como bien lo afirma el gran estudioso de la historia de las religiones y el folklore, Mircea Eliade: «La historia de la medicina podría ofrecernos servicios inestimables para la comprensión de la capacidad metal de una época o para una definición más exacta de un estilo» (2005, p. 135). 38. Aragüés, 2005, p. 250.

39. Aragüés, 2005, p. 258. Por lo tanto, hay que pensar en estas autoridades eclesiásticas antes de santo Tomás y su «Ludus est necesarius ad conservationem vitae humanae».

40. Para evitar caer en la soberbia, pecado del que fueron acusados algunos santos estilitas, debido a su exceso en mortificaciones - llevadas al extremo de vivir sobre una columna-, solían ordenar destruir cualquier testimonio escrito de sus vidas para que no quedara historia de ellos para la posteridad. Ver Palmer, 2014, pp. 9-38.

41. Flos sanctorum con sus ethimologías, ed. Cortés Guadarrama, p. 527.
} 
Mas agora dizen que es en Roma, en la iglesia que es dicha Santa Santorun, en la qual se ley que la carne que fue circuncisa de Jhesu Christo, e el onbligo, claramente es demostrado porque en aquel día se muestra en la iglesia de Santa Santorun; mas si aquesto es verdad, maravilla es que aquella carne sea segund verdad de natura humanal. Nós creemos que quando Jhesu Christo resucitó que la tornó a su cuerpo glorioso ${ }^{42}$.

A esta clase de risa, eutrapélica, moderada, de buen continente, de la reflexión pueril, pertenece la vida san Francisco compilada en este santoral. El de Asís promovió la alegría como uno de los mandatos de su regla43. Además, tomando a la pobreza como su estandarte, el franciscano se volcó a trabajar con la parte más débil de la sociedad, los niños; le otorgó un valor a la infancia hasta entonces inexistente en el plano conceptual de la sociedad feudal y lo adoctrinó en la palabra de Dios. Esto ocurrió desde el siglo XIII en adelante, y es curioso que sea en este mismo periodo cuando Le Goff ve un despunte de lo maravilloso en el plano de la literatura religiosa. El historiador francés percibe una «diversificación en el mundo de lo sobrenatural que permite situar mejor lo maravilloso en relación con la religión cristina» 44 . Quizá, por la revolucionaria postura del franciscano, que se impuso ante los excesos de la corrupción de su época, haciendo gala de una austeridad de tiempos bíblicos ${ }^{45}$; por su novedoso afán de trabajar con la parte más joven y frágil de la sociedad - los niños-, es que el hagiógrafo medieval no tiene el menor problema en recontar una serie de milagros de corte fantasioso que transgreden las leyes de la naturaleza; milagros cuyo estado de pureza y candidez morirán con la Edad Media y evolucionarán hacia formas más fidedignas del milagro en el Renacimiento y en el Barroco, como se verá más abajo, en sus respectivos apartados. Así pues, nos dice que:

Veniendo el siervo de Dios por un camino, venía con él su conpañero, que dezían fray Leonardo. E cansando sant Francisco del trabajo del camino, cabalgó en un asno que traía eso mismo. Fray Leonardo enojado, començó a pensar entre sí, e dezir: «Non son igules los mis parientes e los vuestros». E Luego sant Francisco por Spíritu Sancto súpolo, e descendió del asno, e dixo al fraile: «Hermano, non conviene que cavalgue yo e tú que vayas de pie, ca mejor eres que no yo». Maravillose el fraile, e cayó a sus pies e demandole perdón ${ }^{46}$.

42. Flos sanctorum con sus ethimologías, ed. Cortés Guadarrama, p. 172.

43. "Y guárdense de aparecer tristes, ceñudos e hipócritas; antes muéstrense contentos en el Señor, alegres y religiosamente graciosos» (Primera regla de los frailes menores, capítulo VII, «Del modo de servir y trabajar»). Ver Asís, 1956, p. 9.

44. Le Goff, 2008, p. 14

45. «En la regla de 1221, por ejemplo se señalaba: que era una requisito indispensable para entrar a la orden el dar todas las riquezas personales a los pobres (cap. II); que las vestiduras debían ser viles (cap. II); que los frailes menores fueran pobres de espíritu y sirvieran a los demás (caps. IV, V, VI); que no podían apropiarse ni defender los lugares donde habitasen (cap. VII); que se debían conformar con lo estrictamente necesario para el sustento, para lo cual podían trabajar o en última instancia pedir limosna, pero nunca recibir dinero (caps. VII, VIII y IX); que nunca llevaran nada para el camino ni usaran cabalgaduras». Ver, Rubial, 1996, p. 18

46. Todas las citas de la vida de san Francisco las tomo de mi edición. Ver Flos sanctorum con sus ethimologías, ed. Cortés Guadarrama, CXXII, pp. 616-629. 
Así como se deja en claro que las leyes de la naturaleza sí pueden ser transgredidas (cuando el santo es capaz de leer la mente por intervención del Espíritu Santo), también se muestra, simbólicamente, que en lo profano (cabalgar en un asno) puede intervenir lo sagrado (el milagro de saber lo que piensa el otro). Sin embargo, esto no puede ocurrir a la inversa: en lo sagrado no puede intervenir lo profano. $Y$ para ejemplificarlo, el hagiógrafo noveliza esta idea con una anécdota del día a día: el juego. Ahí más vale dejar las leyes de los hombres para los hombres y las de Dios para Dios, blasfemar conlleva a la muerte:

Un caballero deziendo mal de los miraglos e de las obras de sant Francisco, una [fol. 224b] vegada, jugando a los dados, lleno de locura e de vanidat, dixo a los de arrededor: "Si sant Francisco es santo, venga agora en los dados dies e ocho puntos». E luego parecieron en cada dado seis puntos, fasta IX vezes señas más; encendió su locura, dixo otra locura: «Si verdat es que este Francisco es santo, aun yo sea acochillado, e si él no es santo, escape yo sano». En cabo del juego, porque la su oración fue fecha en pecado, e faziendo tuerto a un su sobrino, tomó un cochillo e metiógelo por el cuerpo e luego murió.

La risa eutrapélica, risa silenciosa por parte del testigo47, en este caso, el lector o escucha de estas anécdotas, se da cuando la candidez maravillosa o, mejor dicho, milagrosa, choca con la realidad austera y opaca del día a día, esa realidad sofocante que necesita de algo más que lo tangible, necesita de la ilusión, de la posibilidad de creer que, gracias al Espíritu Santo, es posible leer la mente o que no se debe blasfemar en un juego de dados. Es precisamente por esa reglamentación de lo milagroso - donde lo controla todo Dios Padre, Hijo y Espíritu Santo- que Le Goff veía un «cierto vaciamiento de lo maravilloso»; una «tendencia a racionalizar lo maravilloso y en particular a despojarlo más o menos de un carácter esencial: el carácter de lo imprevisible» ${ }^{4}$. Pero es justo esta ausencia de lo imprevisible la que da pie a la risa hagiográfica, ya que «es imposible reflexionar sobre la risa sin atender a su relación con la sacralidad» ${ }^{49}$. En efecto, la sutil controlada y apenas dibujada risa hagiográfica, sus breves momentos prominentes, no tendrían sentido sin pasajes ascéticos de sometimiento del cuerpo para evitar que éste se entregue a su instinto natural. Ernst Robert Curtius ${ }^{50}$ dice que: «no hay nada más cómico para el hombre medieval que un desnudamiento involuntario» pero quizá sea un ridiculum más significativo el que, dentro de un discurso de ejemplaridad cristiana, es voluntario, e incluso, dramático:

E viendo el diablo que así non le pudo enpecer, ni vencer, púsole muy grant tentación de la carne. E sentiéndolo el siervo de Dios, depojose todo, e açotose con una cordezuela muy dura, deziendo: «Ea, fraire, ea, asno, así te conbiene fincar». E salió con la tentación fuera, e echose desnudo en la nieve, e tomó la nieve en manera de pella, e fizo siete montones. E echándose en ellas, començó a fablar al cuer-

47. Así lo asume Plessner (1960, p. 146) cuando declara que la comicidad del mundo sólo se revela al espectador desinteresado

48. Le Goff, 2008, p. 15

49. Aragüés, 2005, p. 253.

50. Curtius, 1975 , t. II, p. 615 
po, deziendo: «Ahe, ésta mayor es tu muger, éstas quatro son tus hijas, e las otras dos son el mancebo e la manceba; pues ven agora, e bístelas, que mueren de frío. E si te entristece grant cuidado, sirve a un Señor». El diablo, biéndose confondido, partiose luego dél. E el siervo de Dios tornose a su cámara, dando gracias a Dios.

Este es el tipo de milagro que pervivirá, con sus matices, en siglos posteriores, principalmente en el Barroco; se volverá uno de los tópicos recurrentes en todo franciscano, pues el ideal máximo es ser como el mismísimo fundador de la orden. La oposición cuerpo/alma ha sido una de las batallas más constantes a lo largo de la historia Occidental. Y fue uno de los grandes triunfos del cristianismo, al haber sometido al primero a una serie de ciclos y contingencias dentro de un calendario litúrgico: un tipo de dieta, un número determinado de comidas al día, etc. El cuerpo se concebía como cárcel del alma, en la medida en que se le controlara, el alma podría escapar de su prisión. De esto se desprende la eterna lucha de los santos contra el cuerpo y así lo consiga el hagiógrafo medieval, según él, san Francisco dijo: «Ca yo non he enemigo mayor quel cuerpo». Sometido éste, demostrada la capacidad de dominio sobre uno mismo, la sujeción se extiende hacia el entorno, la naturaleza. Es decir, controlado el microcosmos representado por la carne y sus necesidades biológicas, es posible extender el control hacia el macrocosmos, representado por uno de los seres más admirados por el hombre medieval por su imposibilidad física de imitarlo: las aves, su vuelo, su canto:

Todas las criaturas traía al amor de Dios, predricava a las aves, e oíanle, taníanlas, e no se querían ir dende, fasta que las bendezía e las dava licencia. E las golondrinas, que cantavan mientra él predicava, callavan todas, mandándolo él. [...] En un lugar que dezían [fol. 222a] Porto, muy acerca de la su celda, una ave que dezían ficada, que posava en una figura muchas vezes e cantava, e viéndolo el siervo de Dios, llamó e estendió la mano, deziendo: «O, hermana fincada, ven a mí». Ella obedeciole, e sobió luego en la mano, e díxola él: «Canta agora, hermana fincada, e alava al tu Dios». Ella cantó luego, e nunca se quiso dél partir, fasta que la dio licencia. [...] Fallando el siervo de Dios una vegada muchedubre de aves, saludolas así como si fuese su parcionero, e díxoles: «iO, aves, mis hermanas!, mucho devedes alabar a vuestro cri[fol. 223b]ador, que vos vistió de plumas, e vos dio péñolas para bolar, e vos otorgó andar por el aire e vos govierna sin aver vós cuidado ninguno». E las aves començaron de estender sus colas, e estender las alas, e abrir los picos e parando mientes, catávanle. E él pasando por medio dellas, cobríalas con la saya, mas ninguna dellas non se quería ir sin su licencia. [...] Predicando sant Francisco en castro Almadio, non le podían oír con el roído de las golondrinas, que criavan aí mu[c]has. E díxolas: «iO, hermanas, golondrinas, ya tienpo es que fable oy, que vós asaz dexistes; tened silencio fasta que se acabe la palabra de Dios!». E obedeciéndolo luego, callaron.

El Flos sanctorum con sus ethimologías estaba pensado para un público (lectores u oyentes) más amplio, más allá de los conventos, para un lector más seglar que clerical ${ }^{51}$. Sea quien fuere, que un laico o un religioso aceptaran de buena ma-

51. «Como aquel joven Íñigo de Loyola, Ilamado a una nueva vida tras la lectura del volumen guardado en la casa familiar, en el famoso episodio de su convalecencia». Ver Aragüés, 2014, p. 34. 
nera que es posible controlar el vuelo y el canto de las aves, no quiere decir que tales anécdotas les fuesen insignificantes y vacías. Son momentos diseñados por un hagiógrafo para mover a la sutilísima risa de este género literario, a la alegría dentro de un orden religiosamente gracioso; son breves momentos construidos a partir de lo sagrado - con el mismo propósito con el que se construye un templo religioso- para alejar al fiel de la tristeza y el enojo propias de su tiempo profano, tal y como lo postulaba san Francisco en su opúsculo legislativo. Estos milagros y anécdotas son ejemplos de la risa buena, la risa ascética y cándida que nace de la fe, de la vida ascética y del amor a Dios.

En la prosa del anónimo hagiógrafo medieval de nuestro santoral, a pesar de que se mueve en los extremos de una risa mala y una buena, ya no se percibe el contexto negativo de la risa bíblica, esa risa militante, de burla ante los impíos «risa esencialmente desacralizadora, pero, por lo mismo, y en paradoja tan solo aparente, para toda la autoridad -incluida la del propio Yahvé- condenable por impía y despreciable en tanto símbolo de humana stultitia» ${ }^{52}$.

Efectivamente, por una parte, ahora son los diablos una especie de mina de donde se extrae sucesos risibles, y la paradoja de este hecho es evidente: «Si Satán aportó la risa (scurrilitas, cachinnitas), ahora esta se vuelve en su contra. Y pese a seguir siendo terrible, a partir de entonces se torna ambivalente, sobre todo en la religión popular» ${ }^{53}$. Por otra parte, el hagiógrafo no vacila en que sus protagonistas rompan el halo contario de la risa y disfruten de ella mediante el combate y éxtasis, como la risa de san Lorenzo, pero también, y más importante, de la sutil y momentánea risa eutrapélica, ascética, cándida, pura y llana, que aleja de la tristeza (tristitia) al fiel, al lector u oyente atento.

En siglos posteriores encontraremos algo muy diferente de lo visto hasta ahora. Ya en el siglo XVI, representado en este estudio por una de las crónicas de la conquista espiritual de América, hallaremos una dimensión estética de la risa mucho más desarrollada por los hagiógrafos franciscanos, tal y como se verá a continuación.

\section{EL HAGIÓGRAFO EVANGELIZADOR Y LA RISA RENACENTISTA}

En otro trabajo anterior, dedicado a la risa franciscana y la Historia de los indios de la Nueva España, intenté demostrar, entre otras cosas, que la alegría y la risa ilumina toda zona oscura entre franciscanos e indios adoctrinados; y que, si bien los primeros nunca lograron una utopía real en la Nueva España, es mediante la risa, reflejada en algunos momentos determinados de la crónica, donde mejor se simuló esta tentativa ${ }^{54}$. En el presente apartado me gustaría continuar, en este tenor, con algunas ideas que contrastan de manera complementaria con aquel trabajo. 
Motolinía demostró sus dotes de hagiógrafo al contarnos la vida de fray Martín de Valencia entre las páginas de su obra; no obstante, antes de llegar a ese episodio de su crónica, hay un par de momentos cuya particularidad me resulta de interés para el tema de investigación que aquí desarrollo. El primero, cuando, con base en una circunstancia determinada -la salud y sus procuradores-, la trama se vuelve irónica dentro de la secuencia del relato al oponer dos realidades: la tlaxcalteca y la mexicana. Habla Motolinía del aparejo que tienen los indios tlaxcaltecas para salvarse:

Si a alguno le duele la cabeza o cae enfermo, si algún médico entre ellos fácilmente se puede haber, sin mucho ruido ni costa, vanlo a ver, y si no, más paciencia tiene que un Job. No es como en México, que, cuando algún vecino adolece y muere, habiendo estado veinte días en la cama, para pagar la botica y el médico ha menester cuanta hacienda tiene, que apenas le queda para el entierro, que de responsos y pausas y vigilias le llevan tanto derechos, o tuertos, que quedan adeudada la mujer, y si la mujer muere, queda el marido perdido. Oí decir a un casado, hombre sabio, que cuando enfermase alguno de los dos, teniendo cierta la muerte, luego el marido había de matar a la mujer, y la mujer al marido, y trabajar de enterrar el uno al otro en cualquier cimenterio, por no quedar pobres, solos y adeudados. Todas estas cosas ahorra esta gente ${ }^{55}$.

El registro histórico siempre es fragmentario, más aún cuando se intenta reconocer y dejar por sentado los portentos y horrores de un nuevo mundo hasta entonces desconocido. Un cronista de la evangelización, como Motolinía, tuvo que emplear una imaginación constructiva ${ }^{56}$ para intentar hacer saber de las maravillas que hicieron los trabajos seráficos en los indios y para intentar cubrir un panorama de la conquista -el cual, a sus ojos, resulta reluciente gracias a su profunda convicción profética y milenarista-. Los indios se nos presentan con los dotes de Job, personaje del libro sagrado que se caracteriza por ser un hombre justo que debe padecer múltiples sufrimientos. Su vida es una narración didáctica que enseña que se debe soportar todo, lo bueno y lo malo, porque todo viene de Dios ${ }^{57}$. Así pues, en la confección textual de nuestro hagiógrafo franciscano, el indio tlaxcalteca no es ya un pagano, sino un adoctrinado. En un texto donde hay paganos no hay lugar para la risa buena, pues la risa del pagano es demoníaca, es locura y fealdad58; pero la risa de un adoctrinado es un hecho seráfico, es una risa moderada, tenue, delgada, que adorna los enormes esfuerzos de los frailes menores por transmitir no solo el evangelio, sino de depositar los saberes de toda una cultura occidental en el otro, el indio.

Por otra parte, no deja de ser curioso que, uno de los pocos momentos donde Motolinía se muestra irónico, es para expresar su opinión sobre los médicos. Y su comentario no es para menos. Cuando llegan a la Nueva España los primeros médicos españoles, sabemos que su arte, la medicina, había conocido tiempos

55. Motolinía, Historia de los indios de la Nueva España, I, XIV, p. 81

56. Ver White, 2001, p. 112.

57. «Job», en Sagrada Biblia, ed. Nácar Fuster y Colunga, pp. 583-613.

58. Minois, 2015, p. 161. 
mejores. En efecto, la gran labor de las teorías de la medicina hipocrática y galénica puede resumirse en un hecho determinante: lograron quitar el manto sagrado que la enfermedad poseía en la medicina primitiva. Tanto para Hipócrates, como para Galeno, la enfermedad es un estado de la naturaleza propio de la condición humana, no es un castigo de los dioses o una venganza de los antepasados no recordados mediante el ritual de la ceremonia. Así pues, para el siglo XVI, los practicantes ibéricos del arte de la medicina que se instalaron en el Nuevo Mundo -aun cuando eran conocedores de los avances teóricos de los mencionados médicos grecolatinos, e incluso del mundo árabe, como Rhazes, Avicena, Averroes, etc., y de otros contemporáneos suyos-, practicaban una cura de la enfermedad propia de los primeros tiempos, de la medicina más primitiva ${ }^{59}$, es decir, una medicina que se basaba en remedios rudimentarios, caseros y en la fe. Y como ejemplo, bastaría con recordar la importancia de las reliquias de los santos como métodos infalibles para la cura de distintos males de la salud. Y nada como traer a juego el método que utilizaba Aecio, médico de Justiniano, para extraer un hueso que se le hubiese atragantado a un comensal durante la Edad Media: «Así como Jesús sacó a Lázaro de la tumba y a Jonás de la ballena, así Blasio, mártir y siervo del Señor, manda y ordena: Hueso, sal o vete para abajo» ${ }^{60}$. Con base en estos antecedentes, solo en parte y a efectos prácticos, yo no encuentro mucha diferencia entre el chamán prehispánico y el médico novohispano de la más remota sociedad novohispana. Ambos son «portadores de una herencia que equivale a una vocación-mágico religiosa»; ambos se apartan del «mundo profano porque se hallan en relación más directa con lo sagrado» ${ }^{61}$. En efecto, los dos intentan restituir un orden perdido (la salud), y tratan, por medios diferentes, no científicos, sino más bien artesanales, de lograr tal propósito. Sin embargo, claro que hay diferencias entre el chamán prehispánico y el médico novohispano: en las primeras crónicas de la conquista espiritual de América hay un discurso que se dedica a singularizar el papel del chamán, el papel de lo sobrenatural, contra el médico heredero de un saber occidental, natural.

La verdadera ironía de Motolinía se da en la confrontación de estos dos mundos, el de lo natural, representado por su mundo, su cultura, y el de lo sobrenatural, la cultura del otro. Con base en este razonamiento, no deja de llamar la atención que el más escatológico de los primeros doce franciscanos ${ }^{62}$ nos ofrezca un apartado con este timbre irónico. La explicación la encontraremos en la última finalidad de la risa estética de Motolinía, es decir, ésta ya no es la risa eutrapélica medieval, cándida, y llana, sino la risa combativa del predicador. La risa de Motolinía es la del hagiógrafo que busca convencer, persuadir; el hagiógrafo que busca decir entrelíneas: «creedme a mí, lector, y no a otros» ${ }^{63}$; esta es la risa del predicador que con exempla mueve al lector o al oyente a creer que el tlaxcalteca, paciente como un Job ya per

59. Un ejemplo claro puede leerse en el Tratado breve de medicina, de fray Agustín Farfán impreso en la Nueva España en 1592. Una obra no para médicos, sino para todo aquel que esté lejos de los mismos y donde no haya boticas. Ver Cortés Guadarrama, 2015, pp. 1-24.

60. Aguirre, 1980, p. 23

61. Eliade, 2013, p. 43.

62. Así lo llama Rubial, 1996, p. 130

63. En este tenor está escrita la Carta de 1555 que Motolinía escribió a Carlos V. 
se, solo necesitaba de los nuevos recursos traídos por los franciscanos; recursos que lo sacarían del peligro de la muerte y ayudarían a la vida. Uno de los recursos más vistosos en estos milagros renacentistas será el cordón de san Francisco:

Y sé que particularmente tienen gran devoción con el hábito y cordón de San Francisco, con el cual cordón se han librado muchas mujeres preñadas de partos muy peligrosos. $Y$ esto ha sido en muchos pueblos y muchas veces, y aquí en Tlaxcala en muy común y no ha muchos días que se ha bien experimentado, por lo cual tiene el portero un cordón para darlo luego a los que le viene a demandar, aunque yo bien creo que obra tanto la devoción que con el cordón tienen como la virtud que en él hay, aunque también creo que la virtud no es poca por lo que aquí diré ${ }^{64}$.

El argumento cándido del hagiógrafo medieval está ya muy distante por ese "creo», repetido en dos ocasiones por nuestro hagiógrafo evangelista; ese «creo», que en realidad significa «pienso», termina con la contundencia de lo imprevisible. Nada peor que un milagro glosado por el hagiógrafo para que éste pierda su efecto literario, más allegado a lo folklórico, y entre en los dominios de la doctrina enojosa para el espectador65.

Esta prosa razonada es la misma que encontraremos en la vida de fray Martín de Valencia. Aquí, el máximo de los diablos, Satanás, no encarna ningún pasaje que inspire la burla del mismo, sino apenas una mención argumentativa parca y seca que recuerda al fantasma de la melancolía. El interés de Motolinía no es caracterizar a un héroe con la vocación de Dios manifiesta en lo externo de lo corporal (reprimiéndose al arrojarse a la nieve, como leímos en la vida de san Francisco de Asís), sino mostrar el análisis interior de su protagonista, su duda profunda que atañe a los problemas del alma, de lo íntimo. Cuando el hagiógrafo se concentra en los adentros de su biografiado, lejos quedan las posibilidades de burla que generen la risa y, por el contario, y se hacen próximos los territorios del sermón doctrinal, con dudas vocacionales y existenciales:

Comenzó a tener en su espíritu muy gran sequedad y dureza y tibieza en el corazón, aborrecía el yermo, los árboles le parecían demonios, no podía ver los flaires con amor y caridad, no tomaba sabor en ninguna cosa espiritual, cuando se ponía a orar hacíalo con gran pesadumbre, vivía muy atormentado. Vínole una terrible tentación de blasfemia contra la fe, sin poderla alanzar de sí: parecíale que, cuando celebraba y decía misa, no consagraba, y como quien se hace grandísima fuerza y a regañadientes comulgaba. Tanto le fatigaba aquesta imaginación, que

64. Motolinía, Historia de los indios de la Nueva España, III, I, p. 156. Lo que a continuación contará nuestro franciscano será un milagro que le ocurrió a fray Pedro de Gante: la historia de una familia indígena devota a san Francisco que perdió un hijo; a punto de enterrarlo, gracias a la gran fe de los padres por el de Asís, resucitó el niño.

65. El hagiógrafo del Flos sanctorum con sus ethimologías siempre se cuidó de ser pesado a sus lectores con una enorme carga doctrinal, tal como se lee en la fiesta de la Anunciación de María: «E así podría omne esplanar e esponer todo el evangelio; mas [fol. 71d] sería luengo e enojo. E por ende, contemos algunos miraglos de los que ella fizo oy» (Flos sanctorum con sus ethimologías, ed. Cortés Guadarrama, p. 283). 
ya no quería ya celebrar ni podía comer. Con estas tentaciones habíase parado tan flaco, que no parecía tener sino los huesos y el cuero, y parecíale a él que estaba muy esforzado y bueno esta sotil tentación le traía Satanás para derrocarle, de tal manera que cuando ya le sintiese del todo sin fuerzas naturales le dejase, y así desfalleciese y no pudiese tornar en sí y saliese del juicio66.

Ni siquiera los tópicos franciscanos, aquéllos que imitan los milagros del padre fundador de la orden, tienen el tono de la alegría acordada, feliz, de la risa estudiada en el apartado anterior:

Y entre aquello árboles había uno muy grande debajo del cual se iba a orar por la mañana. Y certifícanme que luego allí se ponía a rezar, el árbol se hinchía de aves, las cuales con su canto hacían dulce armonía, con lo cual él sentía mucha consolación y alababa y bendecía al Señor, y como él se partía de allí, las aves también se iban, y que después de la muerte del siervo de Dios nunca más se ayuntaron las aves de aquella manera ${ }^{67}$.

Nuevamente nos encontramos con los recursos propios de una hagiografía solemne: «certifícanme», es decir, por fuerza se necesita de testigos que den fe de lo maravilloso, pues, en estos tiempos, no importa la anécdota milagrosa per se, sino lo que «siente» el protagonista en estas circunstancias fuera de lo común. Estos implantes renacentistas en la prosa hagiográfica limitan lo risible, tan necesitado de lo chocante, lo imprevisible, lo que sale de la norma, aun cuando sea solo por un breve instante. Al hagiógrafo renacentista le interesa la pesada certificación y el esbozo de lo que yace en el interior del protagonista $y$, de este modo, convierte al milagro en mero argumento reglamentario dentro un discurso religioso. Esto último se lee mejor en los milagros post mortem de fray Martín de Valencia:

Hanme dicho que resucitó un muerto a él encomendado y que sanó una mujer enferma que con devoción le llamó y que un flaire que era afligido de una recia tentación fue por él librado, y otras muchas cosas, las cuales, porque de ello no tengo bastante certidumbre, ni las creo ni las dejo de creer, mas de que como a amigo de Dios, y que piadosamente creo que Dios le tiene en su gloria, le llamo y invoco su ayuda e intercesión ${ }^{68}$.

Lo que en el hagiógrafo medieval es espectacularidad aquí es un mero enlistado que el autor no sabe cómo tomar y por cuál decantarse: «ni las creo ni las dejo de creer». Nuestro hagiógrafo del renacimiento, al no poder ponderar entre creer o no creer, termina por ensayar. La actitud de Motolinía es ciertamente curiosa, sabe que no puede decantarse por una santidad cándida, fantasiosa y universal de sus antepasados y, por ello, sorprendido por la riqueza de un nuevo mundo, protagonista de la expansión territorial que llevó a romper los esquemas y concepciones de las fronteras conocidas hasta los siglos medios, Motolinía prefiere ensayar, contrarrestar sus ideas en distintos niveles de discurso siempre dentro de su profundo mile-

66. Motolinía, Historia de los indios de la Nueva España, III, II, p. 160 
narismo. Por ello es que en su obra hay lugar para la ironía y la seriedad, y también para la risa ascética del padre franciscano que ríe con amor de las torpezas de sus hijos, los indios, recién adoctrinados ${ }^{69}$; hay lugar para la risa combativa del predicador, que seduce a que se le crea que, de las realidades opuestas en su narrativa, la suya, donde él trabaja, es la buena, la mejor. La risa aquí no puede separarse de los aspectos antitéticos de la misma, pues la Historia de los indios de la Nueva España es producto de su tiempo, el Renacimiento, en el cual, hagiógrafos y cronistas, no solo están en los límites y extremos del bien y el mal -como los medievales-, sino que sienten, perciben, piensan, razonan y ensayan sobre su mundo conocido, mucho más amplio de aquél de la Edad Media.

La risa de Motolinía es la del mundo expandido del Renacimiento (en el que se dudaba cuál era la verdadera dimensión del mismo); en este contexto, separar arbitrariamente un fenómeno como la risa de otros impulsos vitales, de sumo interés para el siglo $X V \mathrm{I}^{70}$, sería equivocarnos y mentir, pues la risa siempre ha estado relacionada al llanto -y con éste, la ironía y la seriedad - y viceversa; juntos forman parte de una «teoría de la expresión humana» ${ }^{11}$. Habrá que ir más adelante, al siglo $\mathrm{XVII}$, para que este discurso dé un giro de tuerca y, con los mismos elementos hasta ahora presentados, se cree una atmósfera muy distinta a la analizada hasta ahora.

\section{EL HAGIÓGRAFO CRIOLLO Y LA RISA BARROCA}

Según palabras de Maravall, en los hombres del siglo XVII «se difunde un pesimismo inspirado por las calamidades que durante varias décadas se van a suceder ${ }^{72}$. Y es precisamente en estas circunstancias donde el cuerpo, el mundo al que está ligado la risa, encuentra unos niveles de sensualidad nunca antes vistos. La manera de concebir al cuerpo en esta época verá su representación o interpretación en varios productos estéticos ${ }^{73}$, en algunos textos diseñados para la catequesis y la propaganda ${ }^{74} \mathrm{y}$, por supuesto, en la narrativa hagiográfica ${ }^{75}$.

69. Ver Cortés Guadarrama, 2016a, p. 100.

70. Como lo demuestra el Tratado de la risa, de Laurent Joubert.

71. Plessner, 1960, p. 21.

72. Maravall, 2002, p. 309.

73. Este siglo verá nacer la célebre obra: Gracias y desgracias del ojo del culo (1620), de Francisco de Quevedo y Villegas.

74. Como el Oratio pro crepitu ventris habita ad patres crepitantes ab Emmanuelis Martini, Ecclesiae Alonensis Decani. (Discurso en defensa del pedo que pronunció a los padres pedorros el Sr. Manuel Martí decano de la ciudad de Alicante), de finales del XVII.

75. Otro género literario, importantísimo para el Barroco, es la comedia hagiográfica. Varios especialistas se han preocupado por analizar cómo es que la comicidad, uno de los postulados de la comedia nueva lopesca, entra en un teatro piadoso. Arellano (2007, pp. 8-9), por ejemplo, pone de relieve la vertiente delectare en un corpus de piezas teatrales jesuíticas; aclara que, aunque la comedia nueva incluye elementos cómicos en las tragedias o piezas serias, esto no borra las fronteras genéricas; destaca que los elementos cómicos en este arte son siempre marginales e incidentales, es decir, que podrían extirparse de la pieza teatral sin que ésta pierda sustancia; concluye que el concepto de la risa en los Siglos de Oro suele partir de la propuesta de la Poética, de Aristóteles, en palabras de Cicerón (De oratore) turpido et deformitas; concepto que por fuerza, según Arellano, pide una víctima, sólo así es posible reír de lo torpe, 
Este fenómeno netamente barroco de «pesimismo inspirado por las calamidades» podría rastrearse también en las autobiografías de monjas ${ }^{76}$ del XVII, escritas en un espacio conventual para demostrar, mediante una prosa edificante, la adscripción y pertenencia a un grupo social, con sus propios códigos de comportamiento y entrega ascética ${ }^{77}$. En este género literario de significativa difusión -tanto en el Viejo como en el Nuevo Mundo-, se partía del interior de la biografiada (por ejemplo, la visión que la vincula con su predestinación divina), para, después, llegar a los aspectos externos de su vida (por ejemplo, la historia del convento donde se afanaba por alcanzar sus metas espirituales).

De igual modo, el trabajo hagiográfico de Luis Jerónimo de Oré, antes de llegar a lo corporal, parte de lo interior; concretamente, en su caso, de las virtudes del alma, comenzando con el recuento del niño Francisco Solano. Este inicio -que se debe a la historia del mito del nacimiento del héroe de la literatura folklórica-, en una primera aproximación, nos podría hacer pensar en ese orbe íntimo que leímos de fray Martín de Valencia, en Motolinía. Sin embargo, hay un estilo en la prosa del autor del Barroco que se aleja de la forma de ensayar del hagiógrafo del Renacimiento y nos presenta una frescura inesperada, una candidez que recuerda a la prosa medieval del Flos sanctorum. Nos encontramos ante una adaptación de motivos -nacidos en el medioevo- acorde con la moda textual del XVII, siglo donde la palabra y la imagen lo es todo por encima del vehículo que lo expresa. Es decir, pareciera que no estamos ante las convenciones de un género literario (la vita) que se sostiene, a grandes rasgos, por el miraculum y el exemplum, sino ante simples fragmentos de aire casi laico, meras anécdotas del género biográfico de la época:

Al cual criaron en la niñez con la educación y cuidado de cristianos, enseñándole temer a Dios, y servirle, de lo cual concibió gran deseo, y lo mostró en llegando a tener uso de razón, huyendo como otro Tobías, de las malas compañías en los años pueriles y de los ídolos en la mocedades, a que suelen inclinarse los mancebos mal enseñados; de tal manera procedía, que en las conversaciones dellos, las componía con su presencia, no atreviéndose alguno a decir palabra que no fuese muy decente; y si antes de llegar él, se entretenían en risas y palabras contrarias a la honestidad que en él resplandecía, en llegando se reprimían a callar, y mudaban plática en otra conversación ${ }^{78}$.

lo feo y lo ridículo. Este tipo de risa, aunque pertinente en un arte escénico como la comedia hagiográfica, poco o nada tiene que ver con la hagiografía barroca que aquí se estudia, cuya risa sigue teniendo por eje la alegría ascética y eutrapélica, tal y como lo define el ya citado médico francés del siglo XVI Laurent Joubert en su bello Tratado de la risa: «[Lo que ocurre con la alegría en particular] El rostro se hace más bello en los que están alegres y contentos, debido a cierto fulgor y agradable vivacidad que allí producen los espíritus revoloteando en su piel» (2002, p. 63).

76. Este género literario surgió con un afán proselitista en favor de un momento crítico que sufría la Iglesia Católica frente a la Reforma. Al final de cuentas tuvo muy poco impacto, convirtiéndose en un género menor, llegando a desaparecer de muchos archivos conventuales en España, el Virreinato de la Nueva España y del Perú.

77. Autobiografías que siempre tienen por modelo la vida de santa Teresa de Jesús y ésta, a su vez, la Vita Christi o la Via Mariae. Ver Vinatea, 2016, pp. 411-424.

78. Oré, Relación de la vida y milagros de san Francisco Solano, ed. Cook, I, p. 3. Citaré por esta edición, pero modernizando las grafías y la puntuación. 
Lo barroco ha sido considerado tanto una época como un estilo, esta escisión es arbitraria -y en el fondo equivocada-, sin embargo, entre una u otra, en este caso se subraya que lo barroco, por encima de una época, es un estilo procurado por sus hagiógrafos y predicadores, quienes se lanzan, por ejemplo, a la construcción de un sermón preocupado por encontrar cuál fue la mayor de las finezas de Cristo, ¿haber muerto o habernos abandonado?79 Así pues, lo barroco es el discurso de las finezas. En el caso de fray Luis Jerónimo de Oré queda clara esta narrativa de la sutilidad cuando se pondera, por encima de la potencia taumatúrgica de su protagonista, su potencia argumentativa, su poder de disuadir a otros incluso cuando su héroe todavía no alcanza la edad adulta:

Otra vez hallándose cerca de Montilla en el campo, vio dos hombres reñir con las espadas desnudas, y él fue intrépidamente corriendo a ellos, y a voces les dijo: «Señores, por amor de Dios que no riñan, que no hay quien los pueda poner en paz aquí, y se matarán, lo cual será grande mal»; luego que oyeron tan buenas razones, dichas con deseo y celo de sus vidas, se apartaron el uno a una parte y el otro a otra, y envainando las espadas se fueron en paz, por el buen padrino que Dios les envió para atajar la pendencia ${ }^{80}$.

Probada la valía de la niñez del virtuoso llamado a servir a Dios; probada su capacidad de abstraerse de la naturaleza malvada de los que lo rodean, el hagiógrafo comienza a confeccionar su texto hacia lo exterior, hacia el macrocosmos y, ya en este ámbito, nos muestra la sensualidad de la carne dentro de los motivos franciscanos que inspiran su Relación. El de Asís se entregaba con toda la confianza a los enfermos, los leprosos -incluso llegando a besarlos ${ }^{81}-$; pero ni en la narrativa hagiográfica medieval, ni en la renacentista, leemos los extremos del detalle que se describen a continuación:

Llegando una vez en Montilla a pedir limosna a la puerta de un vecino llamado Diego López, salió su suegra con una criatura en los brazos, hijo de dicho, y pidió al Padre Solano le dijese un Evangelio, porque estaba un niño muy hinchado y enfermo, y en el rostro y por todo el cuerpo tenía muchas llagas. Y el padre fray Francisco dijo a la mujer que descubriese las llagas al niño, y viendo que eran muy grandes, movido de compasión y caridad de ver una criatura con tanto mal, lamió con su boca y lengua las llagas, así las que tenía en el rostro como las que tenía por todo el cuerpo; y dejándolo así, otro día por la mañana amaneció el niño mejor, y todas las llagas secas y sanas, y desde entonces comenzó a caérsele el pellejo de las llagas, y quedó sano del todo, y hoy día vive sano y bueno ${ }^{82}$.

79. Ver Champi, 2000, pp. 195-213.

80. Oré, Relación de la vida y milagros de san Francisco Solano, I, pp. 4-5.

81. El Flos sanctorum con sus ethimologías registra ese ecuentro entre san Francisco y un leproso de la siguiente manera: «Después de una vegada, encontró con un gafo, el qual todos los omnes le aborrecían. E él acordándose del amor de Dios, corrió contra él, e començole de besar. Eluego el leproso despareció (e el leproso era Jhesu Christo), por la qual razón iva sienpre a las casas de los malatos, e besavales las manos muy devotamente e dávales del su aver».

82. Oré, Relación de la vida y milagros de san Francisco Solano, V, pp. 18-19. 
Oré, como buen hagiógrafo, persuade a las autoridades eclesiásticas (últimos destinatarios para quienes escribió) con una Relación que termina por convertirse en un cúmulo de milagros, testificaciones, personas, juramentos, anécdotas, digresiones $^{83}$, comparaciones ${ }^{84}$, alegorías, dietas ${ }^{85}$, capacidades lingüísticas ${ }^{86}$, etc.: una serie de voces polifónicas en busca de su resolución a su tensión; una de esas resoluciones llega con el deleite de la imagen fuertemente contrastada: el santo franciscano lamiendo las llagas de un bebé. Aun cuando la imagen pudiera parecer tremendista, se inserta dentro de los límites de la narrativa biográfica ${ }^{87}$ de amplia popularidad; imagen plenamente aceptada en la ficción que gustaba de estos encuentros chocantes con lo corporal.

Por otra parte, la imagen no solo debe ser de corte tremendista para que se configure en la imaginación del lector de una manera completamente opuesta a la narración hagiográfica del Renacimiento arriba estudiada. Recordemos el milagro del cordón de san Francisco que nos cuenta Motolinía y comparémoslo con el siguiente para ejemplificar esta cuestión:

La misma doña Mencía de Córdoba, estando con dolores de parto, algunos días después de la muerte de su madre, enbió llamar al Padre Solano para confesarse con él, porque no podía parir, por ser recios dolores los que padecía. Y así como entró en casa el Padre Solano, le dijo: «No tenga pena, hermana, que ha de parir un niño muy bonito». El compañero le quitó el cordón al santo Padre, y le pusieron a la preñada, y luego parió; y la comadre [salió] a una sala donde estaba el Padre Solano más afuera de donde estaba la dicha doña Mencía, y le dijo: «Padre, ya ha parido una hija»; el Santo, que sabía lo que era de mejor original, por revelación secreta que se le había hecho, respondió: «Mírelo bien, que no es sino hijo»; y volviendo a mirar, halló que era hijo; y todos se maravillaron de la certeza con que lo afirmó, y salió verdad así como lo dijo 88 .

83. Una de las más importantes es sobre la mejor ruta para llegar a Río de la Plata, se embarcaba en Lima rumbo al reino de Chile «y passada la Cordillera Nevada en menos de quinze días van por la ciudad de Córdova al Río de la Plata» (Oré, Relación de la vida y milagros de san Francisco Solano, IX, p. 31). 84. Se compara al santo del Perú, cuando se embarcó en su viaje trasatlántico, con el profeta Jonás, que «aunque lo tragó una Vallena, no fue ocioso, ni murió en el vientre de aquella bestia marina» (Oré, Relación de la vida y milagros de san Francisco Solano, VIII, p. 27).

85. «Solamente comía pan y algunas frutas: y los Lunes, Miércoles y Viernes de Quaresma, se contentava con sólo pan y agua» (Oré, Relación de la vida y milagros de san Francisco Solano, II, p. 7).

86. «Allanó todas las difficultades, y la mayor que es no saber la lengua de aquellas partes con algún trabajo y estudio que puso en esto, deprendió con suficiencia dos o tres lenguas» (Oré, Relación de la vida y milagros de san Francisco Solano, IX, p. 31).

87. Bastaría con recordar pasajes de la ficticia biografía de don Pablos, como cuando un grupo de estudiantes lo llenan de escupitajos: «Yo estaba cubierto el rostro con la capa y tan blanco, que todos tiraban a mí, iy era de ver cómo tomaban la puntería! Estaba yo nevado de pies a cabeza» (Quevedo, El Buscón, p. 114).

88. Oré, Relación de la vida y milagros de san Francisco Solano, XII, p. 41. 
El tópico de la locura del mundo ${ }^{89}$ alcanza hasta a los productos diseñados para promulgar, dentro de una legalidad impuesta, el proceso de canonización de un venerable del virreinato del Perú. «El siglo barroco se caracteriza por un desmedido incremento de las aspiraciones sociales» ${ }^{90}$. Varios aspiraron a la santidad y sus procesos fracasaron (como los venerables de la Nueva España); pero, más allá de la urdimbre política que se lucubró en el proceso exitoso que aquí se analiza, la Relación de la vida y milagros de san Francisco Solano triunfó por la sabia pluma de un hagiógrafo criollo que, inteligentemente, dio lugar a milagros como éste, el cual reinterpreta la realidad de su tiempo, que lo refleja: el mundo barroco genera desconcierto y por fuerza hay que mirarlo dos veces -como a un niño que se creía niña- para ver su verdadera naturaleza. La risa de esta obra está sutilmente disfrazada, pues, sorprendentemente, es la risa de un burlador que está por encima de «las reglas de su mundo que siente ajeno» ${ }^{97}$; es la risa de un héroe de Dios (Francisco Solano) que, viviendo más allá de lo terrenal, gracias a su vocación y virtud cristianas, sabe desentrañar los secretos de su tiempo y su mundo y, desde esta condición superior, aconseja burlonamente al profano: «Mírelo bien».

El mundo barroco es un mundo al revés, por ello es que, hasta en uno de los más característicos motivos franciscanos, el dominio sobre las aves -el cual, a partir de los ejemplos analizados, debería recordar los estados de pureza y sencillez más claros de la virtud-, está manchado por la sangre y los pellejos. Leemos que:

El Padre Fray Alonso Díaz declaró, y juró en la información que hizo el señor Arzobispo de Lima, que estando en Tucumán en compañía del Padre Solano, yendo a poblar un lugar, llevaba el dicho padre Fray Alonso unas aves en un gallinero para la población que querían hacer; y una noche llegó una zorra al gallinero donde iban unas palomas, y degolló una, y el santo Padre le puso un poco de sebo, y le cortó los pellejos, y echándole la bendición quedó la sana, como si no hubiera pasado algún mal por ella; y de allí adelante se venía esta paloma al santo Padre, y se la ponía en los hombros, y daba de comer en la mano ${ }^{92}$.

La narración de fray Luis Jerónimo de Oré es un texto que cumple con su propósito hagiográfico al mostrarnos un relato edificante en defensa de la vida de un venerable. Se trata de un texto disfrazado de un «estilo fácil y natural de "arte sin arte"»»3 - que coloca las cosas en el lugar que le corresponde-, cuando en realidad su verdadera dimensión es el de una hagiografía de «arte con arte, "un ajedrez de palabras" que en lugar de caer en la tierra, se levanta en el aire» ${ }^{94}$. En efecto, auténticamente no hay nada nuevo en esta risa hagiográfica, pues nace de los motivos franciscanos medievales y renacentistas analizados más arriba. Con fray Luis Jerónimo de Oré tenemos el disfraz barroco impuesto sobre los mismos motivos.

89. Maravall, 2002, p. 311. Todos los tópicos que se mencionan y se marcan en cursivas pertenecen a esta obra, pp. 312-325

90. Maravall, 2002, p. 314.

91. Beltrán, 2016, p.44.

92. Oré, Relación de la vida y milagros de san Francisco Solano, XIV, p. 47.

93. Champi, 2000, p. 203.

94. Champi, 2000, p. 203 
Debemos recordar que, mediante el disfraz, es posible la renovación, la inversión de lo alto en lo bajo que nos lleva al mundo al revés, tópico netamente barroco que puede leerse en esta hagiografía nacida en tiempo de crisis, incertidumbre y desconfianzas arraigados en este mundo como un teatro, donde hay lugar para todos, hasta para un santo que sobrevive a todos los engaños, incluso después de su muerte; esta es, al fin y al cabo, la prueba auténtica de una vida santa: burlar a la descomposición de la carne:

Y fue cosa maravillosa que habiendo pasado 16 horas después de que murió, le cortaron una uña del dedo del pie, y le salió sangre; y también quitándole para reliquias los cabellos del cerquillo de la corona, le dieron algunas heridas, y salió sangre de ellas, y más de 36 horas después que murió estuvieron las heridas coloradas y rojas; y también los labios estuvieron colorados, la lengua fresca y húmeda, que no parescía estar muerto ${ }^{95}$.

\section{CONCLUSIONES}

Algunos de los casos más interesantes de la hagiografía medieval y de los Siglos de Oro fueron diseñados con intenciones públicas y, con ello, con rasgos «novelescos» que seducirían a una audiencia determinada y, hasta cierto punto, amplia: desde el refectorio medieval, hasta los jueces de indias y las autoridades eclesiásticas. Es sorprendente que, en este discurso, que debería responder a cierta legalidad y ciertos patrones aceptados por un riguroso marco oficial cristiano, hay lugar para la risa y el desfogue que la misma supone, incluso cuando esta es sutil y frágil, casi una sonrisa.

La risa pertenece al cuerpo y una literatura tan ligada a lo corpóreo, como lo es la hagiografía, no debe estudiarse sin que se pase por alto este fenómeno humano, tan profundamente ligado a la ética y la estética.

Con este artículo no pretendo leer las cosas como no son. Sé que las tres obras analizadas en este estudio corresponden y son resultado de distintas circunstancias ineludibles. Cabría destacar que el Flos sanctorum es una copia de la Legenda aurea que se aprovechó para difundir la leyenda de algunos santos locales, de gran culto en el norte de la Península Ibérica; la Historia de los indios de la Nueva España, una crónica que iba destinada para ir contra el propósito de las Leyes Nuevas, impresas, finalmente, en 1543; la Relación de la vida y milagros de san Francisco Solano, un documento de corte administrativo que impulsó un proceso jurídico de santificación con fines políticos. Estos hechos yacen presentes en la lectura propuesta en este estudio, pero mi intención es leer bajo la luz de la risa para construir espacios imaginarios que irradien -aunque sea una débil luz- en los ensombrecidos recovecos de uno de los géneros más populares de los Siglos de Oro en ambas orillas del Atlántico: la hagiografía. 
Creo que la hagiografía se debe, entre otras, a una ancha vena propia de la literatura folklórica y, como tal, es portadora de una multiplicidad de símbolos, donde el milagro, la magia, los objetos, las reliquias, los espacios, etc., y la risa «expresan de una forma confusa e incoherente ciertos acontecimientos que la experiencia humana acepta entre sus límites» ${ }^{96}$. El misterio de esa aceptación hecha literatura es una de las experiencias más bellas que puede experimentar el estudioso de estos temas.

\section{BiBLIOGRAFÍA}

Aguirre Beltrán, Gonzalo, Medicina y magia, México, Instituto Nacional Indigenista/ SEP, 1960

Aragüés Aldaz, José, «La difusa autoría del Flos sanctorum. Silencios, presencias, imposturas», en El autor oculto en la literatura española. Siglos XIV a XVIII, ed. Maud Le Guellec, Madrid, Casa de Velázquez, 2014, pp. 21-40.

Aragüés Aldaz, José, «Facecia, apotegma y hagiografía barroca: del ingenio a la stultitia (I). La risa ejemplar», en Practiques hagiographiques dans l'Espagne du Moyen Âge et du Siecle d'Or, ed. Françoise Cazal et al., Toulousse, CNRS/ Université de Toulouse-Le Mirail, 2005, pp. 249-263.

Arellano, Ignacio, «La risa en las comedias jesuíticas sobre san Francisco Javier», en São Francisco Xavier, Porto, Centro Universitario de Historia da Espiritualidades, 2007, pp. 7-26.

Arellano, Ignacio, «Las máscaras de Demócrito: en torno a la risa en el Siglo de Oro», en Demócrito áureo. Los códigos de la risa en el Siglo de Oro, ed. Ignacio Arellano y Victoriano Roncero, Sevilla, Renacimiento, 2006, pp. 329-359.

Asís, Francisco de, Escritos completos y biografías primitivas, Madrid, Biblioteca de Autores Cristianos, 1946.

Bajtín, Mijaíl, La cultura popular en la Edad Media y Renacimiento, Madrid, Alianza, 2003.

Baudot, Georges, La pugna franciscana por México, México CNCA/Alianza Editorial Mexicana, 1990.

Beltrán Almería, Luis, Estética de la risa. Genealogía de humorismo literario, México, Universidad Veracruzana/Ficticia editorial, 2015.

Baños Vallejo, Fernando, Las vidas de santos en la literatura medieval española, Madrid, Ediciones del Laberinto, 2003.

Beristáin, Helena, Diccionario de retórica y poética, México, Editorial Porrúa, 2001. 
Cortés Guadarrama, Marcos, «La risa franciscana en la evangelización novohispana y la Historia de los indios de la Nueva España», La tabla redonda. Anuario de estudios torrentinos, 14, 2016a, pp. 85-104.

Cortés Guadarrama, Marcos, «Ética médica hipocrática en el Flos sanctorum casteIlano medieval», Valenciana. Estudios de Filosofía y Letras, 18, 2016b, pp. 215240.

Cortés Guadarrama, Marcos, «Fuera del canon de la Legenda aurea: la vida de san Antolín en los Flores sanctorum castellano medievales», Archivum, 66, 2016c, pp. 7-44.

Cortés Guadarrama, Marcos, «Una perspectiva literaria de la medicina novohispana del siglo XVI: el Tratado breve de medicina de fray Agustín Farfán», Estudios, 31, II, 2015, pp. 1-24.

Curtius, Ernst Robert, Literatura europea y Edad Media latina, México, Fondo de Cultura Económica, 1975. [dos tomos]

Chiampi, Irlemar, «El Barroco y la utopía de la evangelización», en Barroco y modernidad, México, Fondo de Cultura Económica, 2000, pp. 195-213.

Eliade, Mircea, El chamanismo y las técnicas arcaicas del éxtasis, México, Fondo de Cultura Económica, 2013.

Eliade, Mircea, «El folklore como instrumento de conocimiento», en La isla de Eutanasius, Madrid, Editorial Trotta, 2005.

Eliade, Mircea, Lo sagrado y lo profano, Barcelona, Labor, 1985.

Flos sanctorum con sus ethimologías, ed. Marcos Cortés Guadarrama, Oviedo, Universidad de Oviedo, 2011. Disponible en <http://www.cervantesvirtual.com/ obra/el-flos-sanctorum-con-sus-ethimologias-edicion-y-estudio/>.

Gruzinski, Serge, El pensamiento mestizo. Cultura amerindia y civilización del Renacimiento, Barcelona, Paidós, 2007.

«Job», en Sagrada Biblia, ed. Eloíno Nácar Fuster y Alberto Colunga, O. P., Madrid, Biblioteca de Autores Cristianos, 1985, pp. 583-613.

Joubert, Laurent, Tratado de la risa, ed. Julián Mateo, Madrid, Asociación Española de Neuropsiquiatría, 2002.

La vida sobre una columna. Vida de Simeón estilita (Antonio), Vida de Daniel Estilita (Anónimo), ed. José Simón Palmer, Madrid, Editorial Trotta, 2014.

Maravall, José Antonio, La cultura del Barroco, Barcelona, Ariel, 2002.

Minois, Georges, Historia de la risa y de la burla. De la antigüedad a la Edad Media, México, Universidad de Sonora/Universidad Veracruzana/Ficticia Editorial, 2015. 
Motolinía, fray Toribio Benavente, Historia de los indios de la Nueva España, ed. Mercedes Serna y Bernat Castany, Madrid, Anejos de la Real Academia Española, 2014.

Munguía Zatarain, Martha Elena, La risa y el cuerpo: ¿un estallido de flores?, México, Ediciones sin nombre/CONACYT/Universidad de Sonora, 2012.

Neápolis, Leoncio de, Vida de Simeón el Loco, ed. José Simón Palmer, Madrid, Siruela, 1999.

O'Gorman, Edmundo, La incógnita de la llamada Historia de los indios de la Nueva España, atribuida a fray Toribio Motolinía, México, Fondo de Cultura Económica, 1982.

Oré, Luis Jerónimo de, Relación de la vida y milagros de san Francisco Solano, ed. Noble David Cook, Perú, Pontificia Universidad Católica del Perú, 1998.

Plessner, Helmuth, La risa y el Ilanto, Madrid, Revista de Occidente, 1960.

Quevedo, Francisco de, El Buscón, ed. Pablo Jauralde Pou, Madrid, Castalia, 1990.

Rubial, Antonio, La santidad controvertida, México, UNAM/Fondo de Cultura Económica, 2001.

Rubial, Antonio, La hermana pobreza. El franciscanismo: de la Edad Media a la evangelización novohispana, México, UNAM, 1996.

Thompson, Billy Bussell y John K. Walsh, «Old Spanish Manuscripts of Prose Lives of Saints and their Affiliations. I: Compilation A (The Gran flos sanctorum)», La Corónica, 15:1, 1986-1987, pp. 17-28.

Tozzi, Verónica, «Introducción», en El texto histórico como artefacto literario, Barcelona, Paidós, 2003, pp. 9-42.

Varazze, lacopo da, Legenda aurea, ed. Giovanni Paolo Maggioni, Firenze, Edizioni del Galuzzo, 1998.

Vinatea, Martina, «La vida de María Bautista y de sus milagros, sus adversidades y su ascensión a los cielos», Revista de Literatura, LXXVIII, 156, 2016, pp. 411424.

White, Hayden, El texto histórico como artefacto literario, Barcelona, Paidós, 2003. 